\title{
SISTEM PENDUKUNG KEPUTUSAN FOOD COMBINING DENGAN METODE FORWARD CHAINING
}

\author{
Inez Noviyanti Salim, Robby Kurniawan Budhi, Yonatan Widianto \\ Universitas Widya Kartika Surabaya \\ J1. Sutorejo Prima Utara II-1 Surabaya 60113 \\ e-mail: inez.salim@yahoo.com,robby@widyakartika.ac.id,yonatan@widyakartika.ac.id
}

\begin{abstract}
Public awareness of healthy eating is increasingly formed.However, healthy eating knowledge possessed by each individual is still minimal. This decision support system will use forward chaining method to draw conclusions from the facts already known. Output from the application of this decision support system is the decision whether a food that will be consumed, either for combined or not. The purpose of this research is to create a decision support system of food combining with forward chaining method. This research is expected to help the user in decision making with regard healthy diet food combinations
\end{abstract}

Keywords: decision support system, food combining, forward chaining.

\section{PENDAHULUAN}

Setiap makhluk hidup membutuhkan makanan untuk mengerjakan kegiatan sehari-hari. Pada Kamus Besar Bahasa Indonesia (KBBI) tertulis bahwa definisi makanan adalah segala bahan yang kita makan atau masuk ke dalam tubuh yang membentuk atau mengganti jaringan tubuh, memberikan tenaga, atau mengatur semua proses dalam tubuh. Harmandini (2013) mengungkapkan hasil riset Unilever Food Solutions yang dikemas dalam laporan berjudul "World Menu Report: Seductive Nutrition" bahwa sebanyak 80 persen konsumen Indonesia menginginkan pilihan menu yang lebih menyehatkan. Hasil riset tersebut menunjukan bahwa kesadaran masyarakat Indonesia untuk pola makan sehat sudah mulai terbentuk. Hanya saja, pengetahuan pola makan sehat yang dimiliki oleh tiap individu masih minim. Kebanyakan orang suka makan tetapi ingin badannya tetap kurus. Padahal, tubuh kurus bukan berarti sehat. Untuk mengontrol pola makan, kuncinya bukan dengan mengeliminasi makanan melainkan dengan pengetahuan akan kapan dan bagaimana mengombinasikan makanan.

Menurut Gunawan (2006: 34), kombinasi makanan atau food combining adalah metode pengaturan asupan makanan yang diselaraskan dengan mekanisme alamiah tubuh, khususnya yang berhubungan dengan sistem pencernaan. Pola makan ini berdampak meminimalkan jumlah penumpukan sisa makanan dan metabolisme sehingga fungsi pencernaan dan penyerapan zat makanan menjadi lancar, dan pemakaian energi tubuh juga lebih efisien. Dengan kata lain, food combining memberikan solusi untuk orang-orang yang ingin diet dengan cara yang lebih alami.

Andayati (2010) menyatakan bahwa pengambilan keputusan merupakan penyelesaian suatu masalah berdasarkan fakta-fakta yang dikumpulkan, analisa alternatif penyelesaian, serta pengambilan tindakan penyelesaian yang telah diperhitungkan sebelumnya sehingga diputuskan bahwa tindakan tersebut merupakan tindakan yang paling tepat. Food combining juga tidak jauh dari pengambilan keputusan atas kombinasi makanan yang tepat untuk pola makan yang sehat. Oleh karena itu, sebuah aplikasi sistem pendukung keputusan tentunya dapat membantu masyarakat Indonesia dalam mengenal pola makan sehat dengan memperhatikan kombinasi makanan. Metode yang digunakan adalah metode forward chaining karena forward chaining merupakan metode penarikan kesimpulan dari faktafakta yang telah diketahui. Aplikasi sistem pendukung keputusan disini hanya bertindak sebagai pemberi rekomendasi yang mana bisa bertindak sebagai pendukung keputusan yang akan diambil oleh pengguna.

\section{METODE}

\section{Sistem Pendukung Keputusan}

Andayati (2010) menyatakan bahwa pada dasarnya pengambilan keputusan adalah suatu pendekatan sistematis suatu masalah dengan pengumpulan fakta, penentuan yang matang dari alternatif yang dihadapi, dan pengambilan tindakan yang menurut perhitungan merupakan tindakan yang paling tepat. Sistem Pendukung Keputusan dibuat untuk meningkatkan proses dan kualitas hasil pengambilan keputusan, dimana SPK dapat memadukan data dan pengetahuan untuk meningkatkan efektivitas dan efisiensi dalam proses pengambilan keputusan tersebut.

Little (2004) mengemukakan bahwa sistem pendukung keputusan adalah suatu sistem informasi berbasis komputer yang menghasilkan berbagai alternatif keputusan untuk membantu manajemen dalam menangani berbagai permasalahan yang terstruktur ataupun tidak terstruktur dengan menggunakan data atau model. 


\section{Forward Chaining}

Forward chaining adalah strategi penarikan kesimpulan yang dimulai dari sejumlah fakta-fakta yang telah diketahui, untuk mendapatkan suatu fakta baru dengan memakai rule-rule yang memiliki premis yang cocok dengan fakta dan terus dilanjutkan sampai mendapatkan tujuan atau sampai tidak ada rule yang punya premis yang cocok atau sampai mendapatkan fakta (Durkin, 1994). Lihat flowchart penjelasan Proses Inference Forward Chaining pada Gambar 2.1. Struktur rule secara logika menghubungkan satu atau lebih antecedents (disebut juga premis) dalam bagian $I F$, dan satu atau lebih consequents (disebut juga kesimpulan) dalam bagian THEN (Durkin, 1994).

Berdasarkan gambar 2.1, cara kerja proses forward chaining adalah sebagai berikut:

1. Masukkan inputan informasi pada sistem

2. Sistem kemudian akan memeriksa dengan aturan pertama

3. Apabila ternyata aturan cocok dengan inputan, maka selanjutnya sistem akan memberikan output berupa kesimpulan.

4. Apabila aturan pertama ternyata tidak cocok dengan inputan, maka selanjutnya sistem akan memeriksa apakah ada aturan lain yang atau tidak.

5. Sistem akan berhenti ketika tidak ada aturan lain untuk dicocokan atau ketika output kesimpulan sudah didapat.

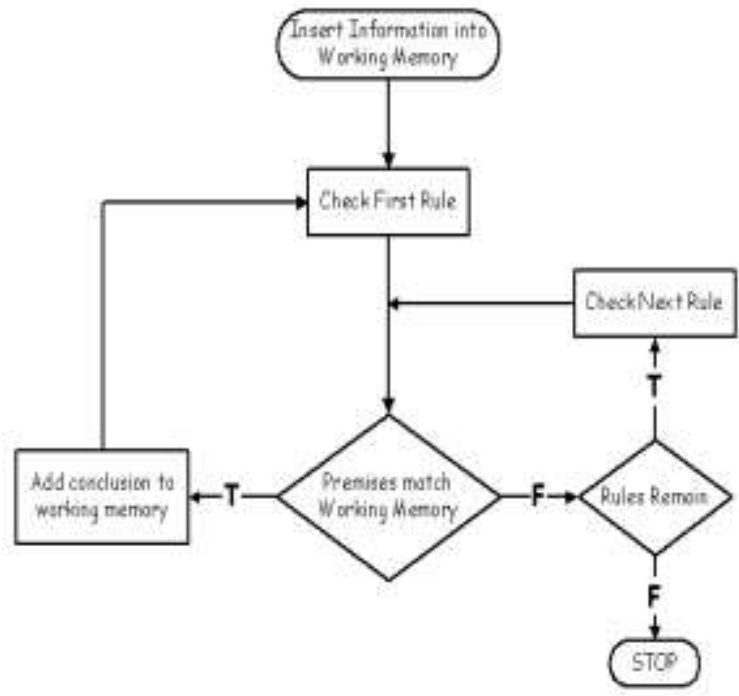

Gambar 2.1. Proses Inference Forward Chaining

\section{Food Combining}

Menurut Gunawan (2006: 34), food combining adalah metode pengaturan asupan makanan yang diselaraskan dengan mekanisme alamiah tubuh, khususnya yang berhubungan dengan sistem pencernaan. Berikut adalah 3 prinsip dasar dalam membentuk pola makan sehat alami dengan panduan food combining (Apriadji, 2007:10):

1. Pilihan makanan sehari-hari diatur mengikuti siklus alami sistem pencernaan.
2. Kombinasi makanan dipilih berdasarkan kebutuhan enzim pencernaan yang bekerja pada kondisi asam-basa berbeda.

3. Menjaga keseimbangan asam-basa tubuh.

Apriadji (2007) menyampaikan food combining bukanlah pola makan yang membatasi. Tidak ada pantangan dan tidak perlu menderita kelaparan karena tidak ada pembatasan porsi makan. Gambar 2.2 merupakan gambar skema aturan food combining yang tepat. Setiap lingkaran yang saling berpotongan merupakan kombinasi makanan yang dianjurkan. Berikut penjelasannya:

1. Melon sebaiknya dimakan sendirian karena waktu cernanya paling cepat

2. Buah Asam dapat dikombinasikan dengan Buah Agak Asam

3. Buah Agak Asam dapat dikombinasikan dengan Buah Asam dan Buah Manis

4. Buah Manis dapat dikombinasikan dengan Buah Agak Asam

5. Protein dapat dikombinasikan dengan Sayuran Berkarbohidrat Tinggi dan Sayuran Berkarbohidrat Rendah

6. Sayuran Berkarbohidrat Tinggi dapat dikombinasikan denganSayuran Berkarbohidrat Rendah dan Protein

7. Padi-padian dapat dikombinasikan dengan Sayuran Berkarbohidrat Rendah

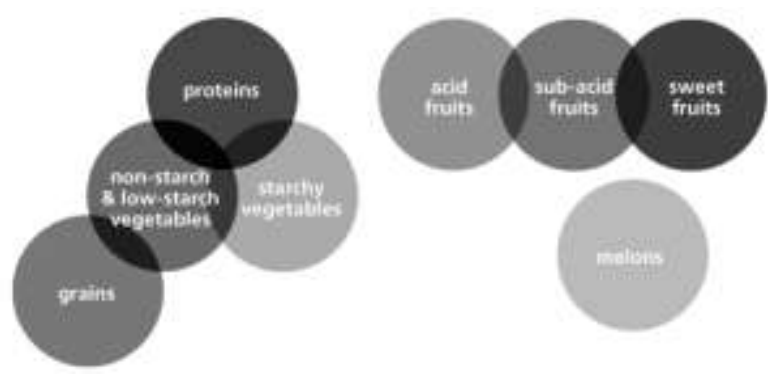

Gambar 2.2 Skema Food Combining

Schatz (2003) memberikan contoh daftar kategori makanan beserta jenis makanannya yang dapat dijadikan pedoman dalam menentukan kombinasi makanan. Contoh daftar tersebut adalah sebagai berikut:

1. Melon:

Canary, Cantaloupe, Casaba, Honeydew, Musk, Persian, Semangka

2. Buah Asam:

Jeruk Keprok, Grapefruit, Kiwi, Lemon, Jeruk Limau, Jeruk, Nanas, Delima, Stroberi, Jeruk Garut

3. Buah Agak Asam:

Apel, Aprikot, Beri, Ceri, Anggur, Nektarin, Persik, Pir, Plum

4. Buah Manis: 
Pisang, Dates, Ara, Mangga, Pepaya

5. Sayuran Berkarbohidrat Rendah:

Arugula, Asparagus, Bok Choy, Pak Choy, Tatsoi, Brokoli, Kubis, Seledri, Jagung, Ketimun, Terong, Kacang Buncis, Bawang Prei, Lettuce, Jamur, Bawang Merah, Kacang Polong, Lada, Lobak, Daun Bawang, Bayam, Labu Musim Panas, Kecambah, Tomat

6. Sayuran Berkarbohidrat Tinggi:

Bit, Wortel, Kentang, Kentang Manis, Labu Musim Dingin,

7. Protein:

Kacang, Telur, Ikan, Susu, Zaitun, Daging Unggas, Daging Merah, Tahu, Tempe

8. Padi-padian:

Gandum Hitam, Jawawut, Havermut, Nasi, Gandum, Tepung

\section{DISKUSI}

\section{Analisa Sistem}

Berikut adalah metode penelitian sesuai dengan waterfall method yang akan digunakan oleh peneliti selama pengerjaan penelitian ini:

1. Tahap Perencanaan

$$
\text { Pada tahap ini dilakukan }
$$
perencanaan pembuatan aplikasi. Perencanaan meliputi penentuan topik serta batasan masalah dari aplikasi, bahasa pemrograman yang akan digunakan, serta jadwal kegiatan pembuatan aplikasi.

2.Tahap Analisis

Studi pustaka adalah studi yang dilakukan dalam rangka untuk mendapatkan pemahaman yang lebih dalam mengenai obyek penelitian secara teoritis dengan mengumpulkan pustaka yang relevan dan penelitian terdahulu dengan masalah yang kurang lebih sama. Studi pustaka ini dilaksanakan dalam tahap analisis.

3. Tahap Desain

Pada tahap ini dilakukan desain sistem dan desain antarmuka aplikasi sistem untuk membangun sebuah aplikasi sistem pendukung keputusan food combining dengan metode forward chaining. Desain sistem meliputi pembuatan diagram flowchart, data flow diagram, conceptual data model, dan physical data model.

4. Tahap Implementasi

Dalam tahap ini $r \begin{array}{r}\text { dilakukan } \\ \text { pengkodean menggunakan }\end{array}$
pemrograman PHP dan database
Kemudian pengujian aplikasi

\section{Tahap Support}

Di tahap ini evaluasi dari keseluruhan kegiatan pembuatan dan pengujian sistem dilakukan. Kemudian ditarik simpulan atas hasil evaluasi. Penelitian ini mengumpulkan dokumentasi dari analisis hasil penelitian seperti diagram rancangan sistem aplikasi dan screenshot dari implementasi aplikasi.

\section{Rancangan Sistem}

Berikut penjelasan kasar mengenai rancangan Sistem Pendukung Keputusan Food Combining dengan Metode Forward Chaining:

1. Administrator harus melakukan login untuk memanajemen data yang ada dalam database aplikasi.

2. Ketika menggunakan aplikasi ini, pengguna umum akan dihadapkan pada rangkaian pilihan jenis makanan

3. Hasil akhir aplikasi ini adalah berupa kecocokan kombinasi makanan berdasarkan hasil inputan pengguna.

Gambar 3.1 adalah gambar rancangan context diagram Sistem Pendukung Keputusan Food Combining dengan Metode Forward Chaining.

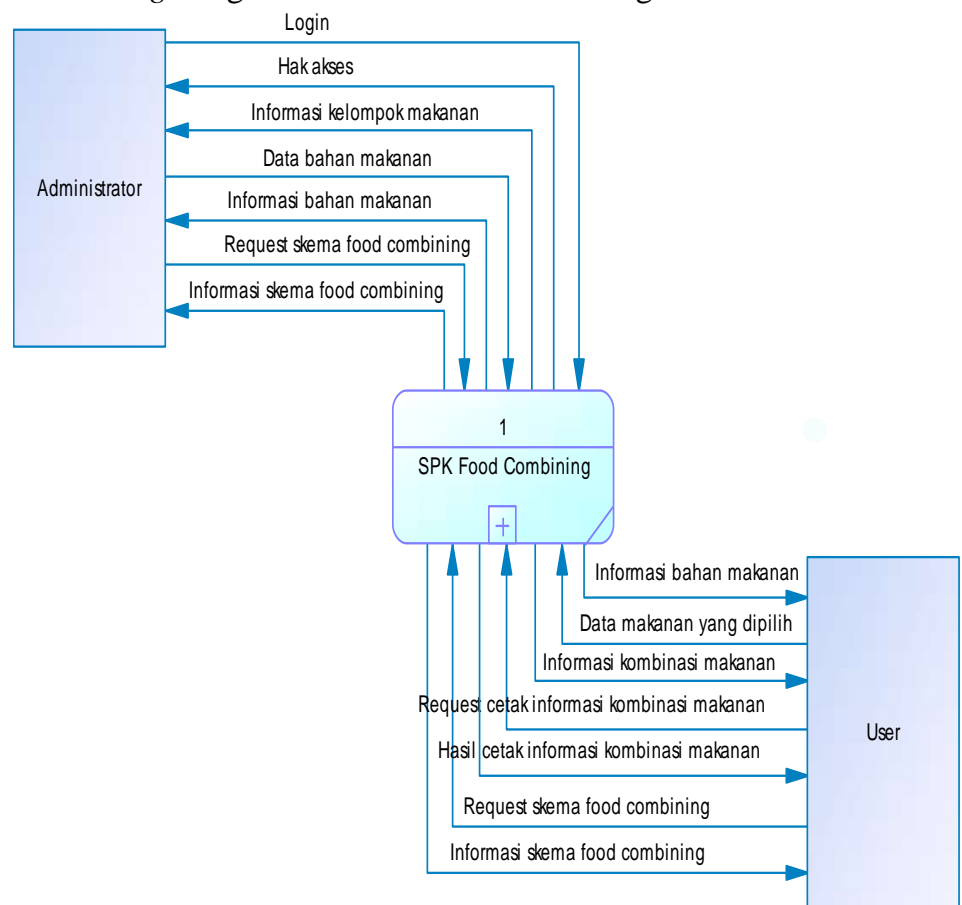

Gambar 3.1. Context Diagram

\section{HASIL}

Aplikasi sistem ini dibuat melalui perangkat lunak pengolah PHP dan menggunakan database MySQL. Aplikasi Sistem Pendukung Keputusan Food Combining ini diimplementasikan secara online melalui media hosting gratis www.idhostinger.com dan bisa diakses melalui browser kapanpun dengan alamat http://herafoodcombining.inez-salim.hol.es/. 
Aplikasi ini sudah diujicobakan pada browser Internet Explorer versi 8.0.6001.18702, Google Chrome versi 33.0.1750.117, serta browser Mozilla Firefox versi 27.0.1. Hasil ujicoba aplikasi pada ketiga browser tersebut berjalan dengan baik.

Tabel 4.1 Tabel Hasil Feedback

\begin{tabular}{|c|c|c|c|c|c|c|c|c|c|c|c|}
\hline No. & Pertanyaan & 1 & 2 & 3 & 4 & 5 & 6 & 7 & 8 & 9 & 10 \\
\hline 1. & $\begin{array}{l}\text { Apakah } \\
\text { Anda sudah } \\
\text { mengenal } \\
\text { Hay Diet } \\
\text { atau Food } \\
\text { Combining } \\
\text { Diet } \\
\text { sebelumnya? }\end{array}$ & 14 & 2 & 3 & 1 & 2 & & 1 & 1 & & \\
\hline 2. & $\begin{array}{l}\text { Apakah } \\
\text { HERA } \\
\text { sudah } \\
\text { membantu } \\
\text { Anda } \\
\text { mengenal } \\
\text { Food } \\
\text { Combining } \\
\text { Diet? }\end{array}$ & 1 & & 2 & & 4 & 4 & 2 & 7 & 2 & 2 \\
\hline 3. & $\begin{array}{l}\text { Apakah } \\
\text { aplikasi } \\
\text { pendukung } \\
\text { keputusan } \\
\text { tersebut } \\
\text { telah } \\
\text { membantu } \\
\text { Anda dalam } \\
\text { mengambil } \\
\text { keputusan } \\
\text { atas } \\
\text { kombinasi } \\
\text { makanan } \\
\text { Anda? }\end{array}$ & 1 & & & & 3 & 4 & 5 & 6 & 2 & 3 \\
\hline
\end{tabular}

Tabel 4.1 adalah hasil yang didapat dari form feedback user. Skala 1 untuk respon sangat negatif dan skala 10 untuk respon sangat positif. Telah terkumpul 24 orang sebagai responden yang telah mencoba aplikasi sistem pendukung keputusan food combining dengan metode forward chaining. 91,6\% responden mengaku tidak pernah mengenal hay diet atau food combining diet sebelumnya. 70,8\% responden menyatakan bahwa aplikasi ini telah membantu mereka untuk mengenal diet food combining. $83,3 \%$ responden menyatakan bahwa aplikasi ini juga telah membantu mereka dalam pengambilan keputusan atas kombinasi makanan.

\section{Kesimpulan \& Saran}

Dari seluruh uraian laporan Tugas Akhir ini, maka penulis menyimpulkan dengan adanya Sistem Pendukung Keputusan Food Combining dengan Metode Forward Chaining dapat membantu user untuk mengenal Food Combining serta menerapkannya dalam pemilihan kombinasi makanan yang baik berdasarkan metode Food Combining.

Adapun beberapa pemikiran berupa saran yang bisa dijadikan pertimbangan untuk perkembangan selanjutnya bagi Sistem Pendukung Keputusan Food Combining ini antara lain:

1. Terus menambahkan data makananmakanan yang masih belum diinputkan sebelumnya guna meningkatkan keakurasian data dalam aplikasi.

2. Menggunakan metode sistem pendukung keputusan yang lain dalam memproses data kombinasi makanan sebagai pembanding.

\section{DAFTAR PUSTAKA}

[1] Andayati, D. 2010. Sistem Pendukung Keputusan Pra-Seleksi Penerimaan Siswa Baru (PSB) On-Line Yogyakarta. Jurnal Teknologi 3,2:145-153.

[2] Apriadji, Wied Harry. 2007. 105 Resep Sedap Cita Rasa Daerah: FOOD COMBINING Makan Enak untuk Langsing dan Sehat. Jakarta: PT. Gramedia Pustaka Utama.

[3] B.V, SCN Education. 2000. Asp--Application Service Providing: The Ultimate Guide to Hiring Rather Than Buying Applications (1 ed.). Germany: Vieweg.

[4] Departemen Pendidikan Nasional. 2008. Kamus Besar Bahasa Indonesia. Jakarta: Balai Pustaka.

[5] Durkin, John. 1994. Expert Systems Design and Development. New Jersey: Prentice Hall.

[6] Gelinas, U. J., Dull, R. B., \& Wheeler, P. R. 2011. Accounting Information Systems (9 ed.): Cengage Learning.

[7] Gunawan, Andang. 2006. Kombinasi Makanan Serzasi: Pola Makan untuk Langsing dan Sehat. Jakarta: Gramedia Pustaka Utama.

[8] Harmandini, Felicitas. 2013. Agar Langsing, Utamakan Kombinasi Makanan. Diakses 27 Oktober 2013, dari

http://female.kompas.com/read/2013/01/24/ 23152294/Agar.Langsing.Utamakan.Kombi nasi.Makanan

[9] Kristanto, Ir. Harianto. 1994. Konsep dan Perancangan DATABASE; Buku Pegangan Kuliah ( 2 ed ). Yogyakarta: ANDI

[10] Little, J. D. C. 2004. Comments On "Models and Managers: The Concept of a Decision Calculus". Manage. Sci., $50(12$ Supplement), 1854-1860.

[11] Oz, E. 2009. Management Information Systems (6 ed.). Boston: Course Technology, Cengage Learning.

[12] Ponniah, P. 2007. Data Modeling Fundamentals: A Practical Guide for IT 
Professionals. New Jersey: John Wiley \& Sons.

[13] Powers, D. 2010. Php Solutions: Dynamic Web Design Made Easy (2 ed.). New York: Apress.

[14] Rahimi, S. K., \& Haug, F. S. 2010. Distributed Database Management Systems: A Practical Approach. New Jersey: John Wiley \& Sons.

[15] Rudi, Moh., Ubaidillah, Achmad. 2013. Sistem Penentu Calon Penerima Beasiswa IKSASS Menggunakan Metode Smarter \& Forward Chaining. Madura: Universitas Trunojoyo Madura.

[16] Schatz, Hale Sofia. 2003. The Right Combination. Yoga Journal, Sept/Oct 2003, p. 49-54. California: Active Interest Media, Inc.

[17] Shelly, G. B., Vermaat, M., Quasney, J. J., Sebok, S. L., \& Freund, S. M. (2011). Discovering computers 2011: Living in a Digital World : Complete. Boston, MA: Course Technology, Cengage Learning.

[18] Simsion, G. C., \& Witt, G. C. 2004. Data Modeling Essentials (3 ed.). San Fransisco, CA: Morgan Kaufmann Publishers.

[19] Taylor, A. G. 2010. Sql for Dummies (7 ed.). New Jersey: John Wiley \& Sons. 